\title{
Behavioral aspects of Helicoverpa armigera in the cotton vegetative phase ${ }^{1}$
}

\author{
Sandra Maria Morais Rodrigues ${ }^{2}$, Nubia do Carmo Santos ${ }^{3}$, \\ Rafael Major Pitta ${ }^{4}$, Janaína de Nadai Corassa ${ }^{3}$
}

\section{ABSTRACT}

Helicoverpa armigera (Hübner) is part of an important complex of insects-pests that attack the cotton crop. This study aimed to identify the preferential plant parts for the oviposition of moths, as well as the movement and feeding behavior of caterpillars, in the vegetative phase of the cotton cultivar BRS 369 RF. Plants emitting floral buds were used to study the oviposition behavior of moths. For this, a completely randomized design, with three treatments (adaxial and abaxial sides of the leaf and floral buds) and twenty replications (plants in pots), was used. In order to evaluate the behavior of the caterpillars in the cotton vegetative phase, another $3 \times 5$ factorial design, with nine replications, was used. The treatments were three ages (first, second and third instars) combined with five behaviors (walking, resting, waving, eating and drop-off). In this trial, the period of the day when caterpillars are more active was also evaluated. It was observed that $H$. armigera moths prefer to lay their eggs on the adaxial leaf side and on the last two nodes of the plant, in a descending direction. The adaxial leaf side is also the part of the plant preferred by caterpillars for walking, eating and resting, being this last behavior the most frequent in all instars. In general, the caterpillars walk more in the morning.

KEYWORDS: Gossypium hirsutum, Heliothinae, ethology.

\section{INTRODUCTION}

Brazil is among the largest cotton producers and the planted area in the 2017/2018 crop season was $1,176.1$ thousand hectares, with an expected production of 4,947,000 tons of cotton seed and 1,979.4 thousand tons of fiber. The Central-West region is responsible for $70.4 \%$ of this production, where the

\section{RESUMO}

Aspectos comportamentais de Helicoverpa

armigera na fase vegetativa do algodoeiro

Helicoverpa armigera (Hübner) faz parte de um importante complexo de insetos-pragas que atacam a cultura do algodoeiro. Objetivou-se identificar partes da planta preferenciais para a oviposição das mariposas, bem como os comportamentos de movimentação e alimentação das lagartas, na fase vegetativa da cultivar de algodão BRS 369 RF. Plantas emitindo botões florais foram utilizadas para estudar o comportamento de oviposição das mariposas. Para isso, utilizou-se delineamento inteiramente casualizado, com três tratamentos (faces adaxial e abaxial da folha e botões florais) e vinte repetições (plantas em vasos). Para avaliar o comportamento das lagartas na fase vegetativa do algodoeiro, adotou-se outro delineamento fatorial $3 \times 5$, com nove repetições. Os tratamentos foram três idades $\left(1^{\circ}, 2^{\circ}\right.$ e $3^{\circ}$ ínstares) combinadas com cinco comportamentos (caminhar, repousar, acenar, comer e cair). Neste ensaio, o período do dia em que as lagartas são mais ativas também foi avaliado. Constatou-se que as mariposas de H. armigera preferem ovipositar na face adaxial da folha e nos dois últimos nós da planta, em direção descendente. A face adaxial da folha também é a parte da planta preferida pelas lagartas para caminhar, comer e repousar, sendo este último comportamento o mais frequente em todos os ínstares. Em geral, as lagartas caminham mais no período matutino.

PALAVRAS-CHAVE: Gossypium hirsutum, Heliothinae, etologia.

Mato Grosso state is the largest producer, with 777.8 thousand hectares of cotton, corresponding to $66.1 \%$ of the area planted in the country. The projected cotton seed production for this state is 3,213.9 thousand tons, $27.1 \%$ higher than in the 2016/2017 harvest, with a yield of 4,132 $\mathrm{kg} \mathrm{ha}^{-1}$ (Conab 2018).

The crop is attacked by a complex of insectspests capable of infesting all the phenological plant

1. Received: Oct. 30, 2018. Accepted: Apr. 17, 2019. Published: Oct. 15, 2019. DOI: 10.1590/1983-40632019v4955628.

2. Empresa Brasileira de Pesquisa Agropecuária (Embrapa Algodão), Campina Grande, PB, Brasil.

E-mail/ORCID: sandra.rodrigues@embrapa.br/0000-0001-9043-4694.

3. Universidade Federal de Mato Grosso, Instituto de Ciências Agrárias e Ambientais, Sinop, MT, Brasil.

E-mail/ORCID: nubiadocarmo@hotmail.com/0000-0001-9923-4437, janadenadai@gmail.com/0000-0002-1013-5414.

4. Empresa Brasileira de Pesquisa Agropecuária (Embrapa Agrossilvipastoril), Sinop, MT, Brasil.

E-mail/ORCID: rafael.pitta@embrapa.br/0000-0002-8503-7106. 
phases (Santos 2015), and its production may be significantly reduced if control measures are not adopted at the right time. Within this complex is Helicoverpa armigera (Hübner) (Lepidoptera: Noctuidae), a pest detected in Brazil in 2013, in soybean and cotton crops (Czepak et al. 2013). This pest is important worldwide, because it has a wide geographic distribution, polyphagous behavior and high biotic potential (Zalucki et al. 1986, Behere et al. 2013, Silva et al. 2018).

Heliothinae moths prefer to feed and oviposit on plants that contain flowers and nectar (Cunninghan \& Zalucki 2014). The females oviposit in cotton at night and eggs are laid single (Topper 1987, Ahmad 2004). The attack may begin in the vegetative phase, with small caterpillars consuming the leaves (Pascua \& Pascua 2002), and then later in the reproductive phase, with larger caterpillars feeding on flower buds, flowers and bolls (Gomes et al. 2017). Experimental evidence for learning of $H$. armigera has demonstrated that a previous experience with a host species increases the relative attractiveness of that host (Cunningham et al. 1998). Therefore, preferences for different hosts displayed by adult moths which have encountered a host species may be vastly different from the preferences of moths without any host experience (Cunningham et al. 1999).

The main method for controlling this pest has been to use synthetic insecticides, what is often performed inadequately (Costa et al. 2018). The continuous use of insecticides has selected populations of pests which are resistant to various molecules (Mota-Sanches \& Wise 2018). Another factor related to the ineffectiveness of insecticides is the pest location in parts of the plant which hinder the deposition of insecticide drops, thus compromising the minimum amount of active ingredient to cause the target death (Costa et al. 2018). In order to perform both sampling and application of insecticides efficiently, it is necessary to know the habits of the target insect. Considering that caterpillars in the first instars are more vulnerable to insecticides, knowing the behavior of the pest in these stages is fundamental to assist in the decision-making on managing this pest. Such information will enable detecting how best to sample the insect in the field, as well as in what period of the day it will be most exposed to the applied chemicals.

Due to the importance of $H$. armigera in the Brazilian cotton crop, this research aimed to study the moths' preferential oviposition plant sites in the reproductive phase of the cotton crop, as well as the caterpillars' behavior of the 1st, 2nd and 3rd instars, in the vegetative phase of the cotton crop.

\section{MATERIAL AND METHODS}

The experiments were carried out at the Embrapa Agrossilvipastoril (Sinop, Mato Grosso state, Brazil), in 2017. The moths and caterpillars used were obtained from those reared in laboratory, fed with an artificial diet proposed by Parra (2001). The use of an artificial diet removed the possibility of alterations in the adult behavior due to host plant experience in the larval stage. Seeds of the BRS 369 RF cotton cultivar (not Bt) were sown into $5 \mathrm{~L}$ pots and kept in a greenhouse, and the cotton plant received the necessary cultural treatment for its development.

When the plants began to emit flower buds, they were then taken to the laboratory and housed in a cage $(1 \mathrm{~m} \times 1 \mathrm{~m} \times 1 \mathrm{~m})$, in groups of five plants, and kept in a controlled environment $\left(25 \pm 1{ }^{\circ} \mathrm{C}\right.$ and $60 \pm$ $1 \% \mathrm{RH})$, with a $13-\mathrm{h}$ scotophase, since oviposition occurs at night (Topper 1987). The moths used had $72 \mathrm{~h}$ of emergence and were previously mated and fed with a honey solution. At 6 p.m., the moths were released into the cages and remained in the plants for $13 \mathrm{~h}$. The ratio used was one moth to each plant and, in the following morning, the number of eggs deposited on the adaxial and abaxial surface of the leaves and floral buds were counted, as well as the vertical distribution of the eggs on the plants.

To study the oviposition behavior of moths, a completely randomized design, with three treatments (adaxial and abaxial leaf surface and floral buds) and twenty replications (plants in pots), was used. For the statistical analysis, the data were transformed by $\sqrt{ }(x+1)$, to correct the heterogeneity of the variances before being submitted to the analysis of variance (Anova), and the means were compared by the Scott-Knott test when there were significant treatment effects $(\alpha=0.05)$. The number of nodes constituted the treatments in the vertical distribution of the eggs on the plant. The nodes refer to the place where the branch goes out from the stem and were counted upwards, being located just above the cotyledon node. The data were analyzed with the same aforementioned procedure.

The separation of the caterpillars by instar was done by observing the replacement of the cephalic capsule. Plants ranging between V4 and V5 were 
used to evaluate the behavior in the vegetative phase, according to the scale by Marur \& Ruano (2001). The first evaluation was carried out $20 \mathrm{~min}$ after distributing the caterpillars on the leaves. The caterpillars remained on the plants for $12 \mathrm{~h}$, from 6 a.m. to 6 p.m., and the ratio used was one caterpillar per plant, with no replacement or disposal of caterpillars. The crawling, resting, waving, feeding and drop-off behaviors were observed regarding the frequency of use of the different plant sites. Waving, according to Johnson \& Zalucki (2005), is when the caterpillar has its front legs raised and shakes its head from side to side, and this indicates a search behavior. The observations were made with the aid of a pocket magnifying glass (40x magnification) and performed every $30 \mathrm{~min}$. Furthermore, the period of the day when the largest larval movement occurs and which plant region is preferred by the caterpillars to carry out the five behaviors were also evaluated.

To study the caterpillar behavior in the cotton vegetative phase, other completely randomized design, with nine replications, was used. First, the treatments were assumed in a $3 \times 5$ factorial scheme, in which three ages (1st, 2nd and 3rd instars) were combined with five behaviors (crawling, resting, waving, feeding and drop-off). To evaluate the period of the day when caterpillars are more active, the treatments assumed a $3 \times 2$ factorial, combining the three instars with two periods of the day (morning and evening). Similarly, to identify the plant region preferred by the caterpillars, another 3 x 5 factorial was assumed, in which the treatments were the three ages combined with five plant parts (adaxial surface, abaxial surface, leaflet, stem and petiole). Data analyses were the same as described before, using transformations as $\sqrt{ }(x+0.5)$ (for count data) or arcoseno $\sqrt{ }(\mathrm{x}+0.5)$ (for percentage data) to correct the heterogeneity of the variances.

\section{RESULTS AND DISCUSSION}

The moths oviposited on the adaxial and abaxial leaf surfaces and floral bud (Table 1). It was found a significant difference between treatments by the Scott-Knott test $(p=0.05)$. Even without a prior experience and not knowing a cotton plant, moths oviposited in all parts of the evaluated plants. Cunnighan et al. (1999) reported that the inexperience with the host plant may influence the selection of hosts by the moth, but this did not occur in this research.
The adaxial surface (18.7 eggs) was the most preferred, followed by the abaxial surface (13.5 eggs) and the floral bud (3.4 eggs) (Table 1), similarly to the results observed by Butter \& Singh (1996), in cotton. It was found that the eggs present on the adaxial surface of the leaf were generally on the leaf veins which have trichomes. It is known that the plant morphological and chemical characteristics are involved in choosing the oviposition site (Navasero \& Ramaswamy 1991). Sites with trichomes are probably chosen by $H$. armigera to oviposite (Zalucki et al. 1986, Luong et al. 2016) because these structures may hinder the movement of natural enemies when searching for their prey or hosts, resulting in protection for the pests' progeny (Vendramim 2002).

A significant difference was observed between the nodes, regarding the vertical distribution of the eggs in the plant. All nodes presented leaves with the presence of eggs, except the node one. The largest ovipositions occurred at nodes 8 (6.2 eggs) and 9 (6.5 eggs), corresponding to the nodes at the top of the plant (Figure 1). Its preference for the upper third of the plant is closely related to its food habit, since it mainly attacks flower buds and cotton flowers that are concentrated in the middle and upper thirds of the plant. Olsen \& Daly (2000) also verified this fact in cotton and Santos et al. (2017) in soybean, a behavior also found in Chloridea virescens and H. zea Heliothinae (Torres \& Ruberson 2006).

Regarding the behaviors of the caterpillars in the cotton vegetative phase, no difference $(\mathrm{p}>0.01)$ among the $H$. armigera instars was observed (Figure 2). However, differences were observed $(p<0.01)$ when analyzing the behavior within each instar.

During the evaluation period of each instar, it was observed that the caterpillars often presented alternating behaviors. In the three studied instars, it was noticed that the caterpillars most frequent behavior was to rest, and this differed from the others.

Table 1. Means and standard errors (SE) for number of eggs per plant of Helicoverpa armigera moths in cotton plants.

\begin{tabular}{lc}
\hline \multicolumn{1}{c}{ Treatment } & Mean $\pm \mathrm{SE}^{1,2}$ \\
\hline Adaxial leaf surface & $18.7 \pm 2.13 \mathrm{a}$ \\
Abaxial leaf surface & $13.5 \pm 2.38 \mathrm{~b}$ \\
Floral bud & $3.4 \pm 0.68 \mathrm{c}$ \\
\hline CV $(\%)$ & 33.04 \\
\hline
\end{tabular}

Original data. ${ }^{2}$ Means followed by the same letter do not differ by the Scott-Knott test at $5 \%$ of significance [for the analysis, data were transformed to $\sqrt{ }(x+1)$; F-test $=18.93 ; \mathrm{p}<0.001 ;$ d.f. $=37]$. 


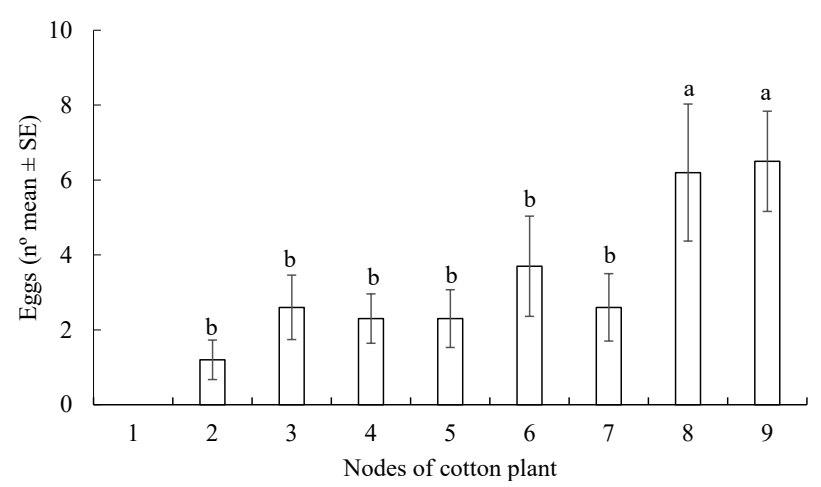

Figure 1. Means and standard errors (SE) for number of eggs of Helicoverpa armigera moths in different nodes of cotton plants. Means followed by the same letter do not differ by the Scott-Knott test at $1 \%$ of probability.

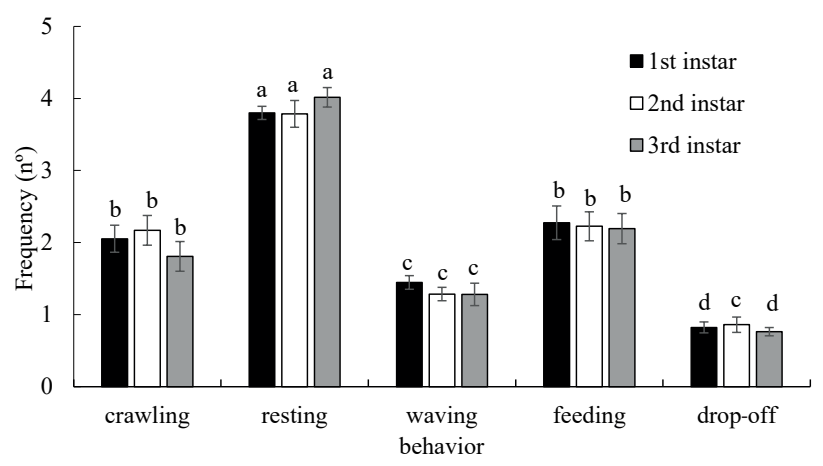

Figure 2. Behavior of Helicoverpa armigera larvae on cotton plants by instar. Mean frequency followed by the same letter, within each instar, do not differ by the ScottKnott test at $1 \%$ of probability. The bar above each column is the standard error of the respective mean.

The fact that resting occurs more often is possibly related to the digestive process of caterpillars. The crawling and feeding behaviors were similar for the three evaluated instars. Johnson \& Zalucki $(2005,2007)$ obtained results similar to those of the present study, when they evaluated the behavior of $H$. armigera in the vegetative stage of Vigna radiata L. However, the first and third instars in this research differed for the waving and drop-off behaviors on the plant, with waving being more frequent than drop-off.

Regarding the period of the day when the caterpillar moved the most, an absence of interaction between period and instars in all the evaluated behaviors was observed, except for the crawling variable, since it was verified that all instars move more in the morning (Table 2). The caterpillars movement on the plant may increase the probability of finding food with higher nutritional quality, as well as natural enemies (Johnson \& Zalucki 2005). Control tactics based on the period of day that the caterpillar moves the most may be established, what increases the probability of reaching the target pest, since it will be more exposed.

During the evaluation period in the instars, it was observed that the caterpillars moved in different regions of the plants, and a generally similar behavior pattern was observed in the analysis of these regions (Figures 3, 4 and 5). First-instar caterpillars always preferred the adaxial surface for crawling (Figure 3), resting (Figure 4), waving (Figure 5) and feeding (Figure 6), differing from other sites on the plant. For the acts of crawling and waving, there was no significant difference between the abaxial surface, leaflet, stem and petiole, while, for resting and feeding, the abaxial surface of the leaf differed from the rest of the treatments.

Table 2. Means and standard errors (SE) for crawling frequency (\%) of Helicoverpa armigera larvae, at two periods of the day, on cotton plants.

\begin{tabular}{lrcc}
\hline \multirow{2}{*}{ Instar } & \multicolumn{2}{c}{ Period } & \multirow{2}{*}{ Mean $^{1,2}$} \\
\cline { 2 - 3 } & Morning & Evening & \\
\hline First & $7.6 \pm 2.78$ & $8.0 \pm 2.21$ & $7.8 \pm 1.73 \mathrm{a}$ \\
Second & $12.4 \pm 3.23$ & $5.8 \pm 1.78$ & $9.1 \pm 1.96 \mathrm{a}$ \\
Third & $7.6 \pm 2.05$ & $4.4 \pm 2.05$ & $6.0 \pm 1.46 \mathrm{a}$ \\
\hline Mean & $9.2 \pm 1.58 \mathrm{~A}$ & $6.1 \pm 1.16 \mathrm{~B}$ & $\mathrm{CV}(\%)=51.81$ \\
\hline
\end{tabular}

Original values. ${ }^{2}$ Means followed by the same lowercase letter in the column, or upper case in the row, do not differ from each other by the F-test at $5 \%$ of significance.

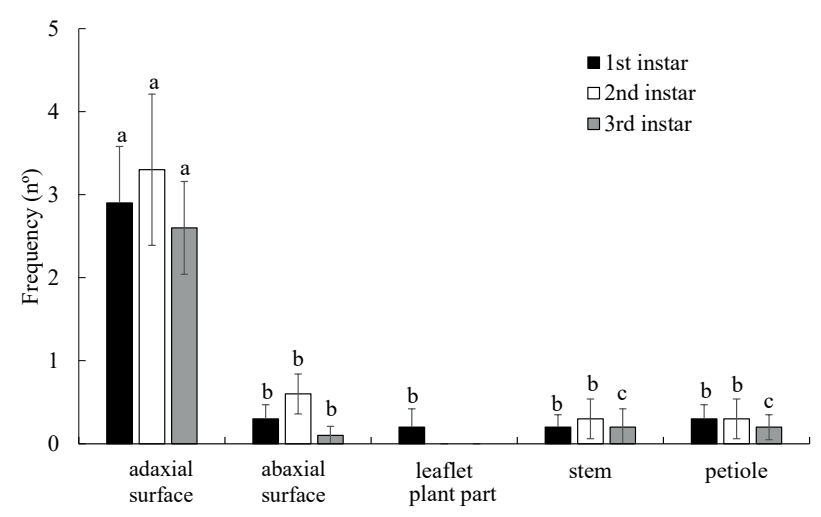

Figure 3. Preference of Helicoverpa armigera larvae to crawling in cotton plant parts, in the vegetative phase, by instar. Mean frequency followed by the same letter, within each instar, do not differ by the Scott-Knott test at $1 \%$ of probability. The bar above each column is the standard error of the respective mean. 


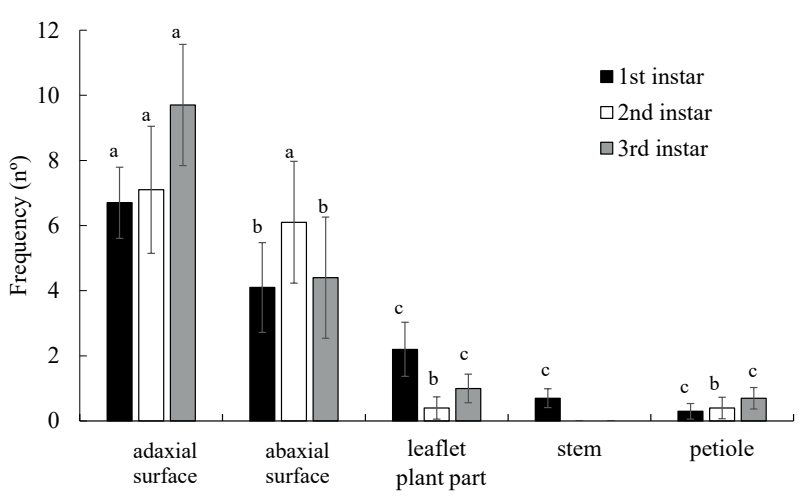

Figure 4. Preference of Helicoverpa armigera larvae to resting in cotton plant parts, in the vegetative phase, by instar. Mean frequency followed by the same letter, within each instar, do not differ by the Scott-Knott test at $1 \%$ of probability. The bar above each column is the standard error of the respective mean.

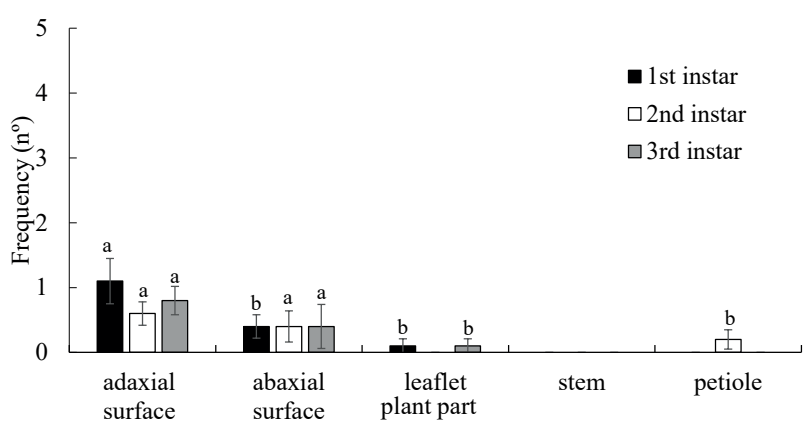

Figure 5. Preference of Helicoverpa armigera larvae to waving in cotton plant parts, in the vegetative phase, by instar. Mean frequency followed by the same letter, within each instar, do not differ by the Scott-Knott test at $1 \%$ of probability. The bar above each column is the standard error of the respective mean.

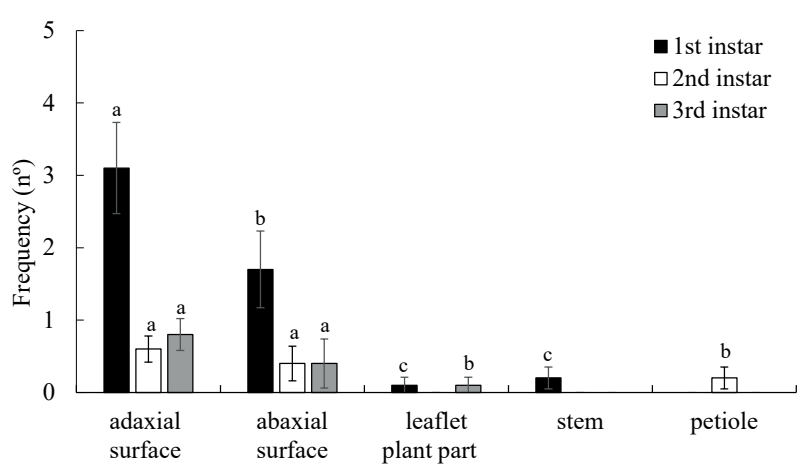

Figure 6. Preference of Helicoverpa armigera larvae to feeding in cotton plant parts, in the vegetative phase, by instar. Mean frequency followed by the same letter, within each instar, do not differ by the Scott-Knott test at $1 \%$ of probability. The bar above each column is the standard error of the respective mean.
When evaluating the second-instar caterpillars for crawling (Figure 3) and feeding (Figure 6), it was noted that the preferred region was also the adaxial surface of the leaf. For the acts of resting (Figure 4) and waving (Figure 5), there was no significant difference when comparing the adaxial with the abaxial surface, but these behaviors differed from the others.

In relation to the third-instar caterpillars, the adaxial surface of the leaf is again observed for crawling (Figure 3), resting (Figure 4) and feeding (Figure 6), while the caterpillars preferred the adaxial and abaxial surfaces, regarding the waving behavior (Figure 5).

The caterpillars of the first three instars generally preferred the adaxial surface of the cotton leaf to move, rest and eat. This preference may be associated with a positive phototropism, which is a common behavior in lepidoptera (Perkins et al. 2008). Johnson \& Zalucki (2007) also reported that third-instar H. armigera fed more frequently on exposed areas of mature $V$. radiata leaves. However, this result differs from that obtained by Cribb et al. (2010), who verified first-instar $H$. armigera caterpillars searching for closed spaces and positioning themselves on the abaxial surface of pea leaves, when there was light. The divergence between the results obtained in this research and those of other authors may be related to the fact that the feeding site chosen by a caterpillar is influenced by factors such as plant architecture, light intensity, nutritional value, presence of trichomes and wax, microclimate and volatiles (Navasero \& Ramaswamy 1991, Cribb et al. 2010, Perkins et al. 2013). Costa et al. (2018) reported that the highest deposition of insecticides was observed in the upper third of cotton plants, when they used $140 \mathrm{~L} \mathrm{ha}^{-1}$ and $194 \mathrm{~L} \mathrm{ha}^{-1}$ flow rates. As the larvae of these instars are often on the adaxial surface and prefer to move in the morning, this indicates that they will be exposed to sprays.

\section{CONCLUSIONS}

1. Helicoverpa armigera moths prefer to oviposit on the adaxial leaf surface and in the upper third of the cotton canopy;

2. H. armigera caterpillars crawl more in the morning, and the adaxial cotton leaf surface is also the plant region preferred by caterpillars for crawling, feeding and resting, regardless of the age (first, second or third instars). 


\section{REFERENCES}

AHMAD, M. A comprehensive review on cotton bollworm, Helicoverpa armigera (Hübner). Journal of Agricultural Research, v. 42, n. 1, p. 73-106, 2004.

BEHERE, G. T.; TAY, W. T.; RUSSEL, D. A.; KRANTHI, K. R.; BATTERHAM, P. Population genetic structure of the cotton bollworm Helicoverpa armigera (Hübner) (Lepidoptera: Noctuidae) in India as inferred from EPIC PCR DNA Markers. Plos One, v. 8, n. 1, e53448, 2013.

BUTTER, N. S.; SINGH, S. Ovipositional response of Helicoverpa armigera to different cotton genotypes. Phytoparasitica, v. 24, n. 2, p. 97-102, 1996.

COMPANHIA NACIONAL DE ABASTECIMENTO (Conab). Acompanhamento da safra brasileira de grãos: décimo primeiro levantamento. 2018. Available at: www. conab.gov.br. Access on: 10 Sept. 2018.

COSTA, A. G. F.; MIRANDA, J. E.; PERINA, F. J.; WADT, L. G.; CHAIM, A. Aspectos da tecnologia de aplicação para o manejo de lepidópteros-praga. Luís Eduardo Magalhães: Fundação de Apoio à Pesquisa e Desenvolvimento do Oeste Baiano, 2018. (Boletim técnico, 5).

CRIBB, B. W.; HANAN, J.; ZALUCKI, M. P.; PERKINS, L. E. Effects of plant microenvironment on movement of Helicoverpa armigera (Hübner) larvae and the relationship to a hierarchy of stimuli. Arthropod-Plant Interactions, v. 4, n. 1, p. 165-173, 2010.

CUNNINGHAM, J. P.; ZALUCKI, M. P. Understanding Heliothine (Lepidoptera: Heliothinae) pests: what is a host plant? Journal of Economic Entomology, v. 107, n. 3 , p. 881-896, 2014.

CUNNINGHAN, J. P.; WEST, S. A.; WRIGHT, D. J. Learning in the nectar foraging behavior of Helicoverpa armigera. Ecological Entomology, v. 23, n. 4, p. 363-369, 1998.

CUNNINGHAN, J. P.; ZALUCKI, M. P.; WEST, S. A. Learning in Helicoverpa armigera (Lepidoptera: Noctuidae): a new look at the behaviour and control of a polyphagous pest. Bulletin of Entomological Research, v. 89, n. 3, p. 201-207, 1999.

CZEPAK, C.; ALBERNAZ, K. C.; VIVAN, L. M.; GUimarÃES, H. O.; CARVAlHAis, T. Primeiro registro de ocorrência de Helicoverpa armigera (Hübner) (Lepidoptera: Noctuidae) no Brasil. Pesquisa Agropecuária Tropical, v. 43, n. 1, p. 110-113, 2013.

GOMES, E. S.; SANTOS, V.; ÁVILA, C. J. Biology and fertility life table of Helicoverpa armigera (Lepidoptera: Noctuidae) in different hosts. Entomological Science, v. 20, n. 1, p. 419-426, 2017.
JOHNSON, M. L.; ZALUCKI, M. P. Feeding and foraging behaviour of a generalist caterpillar: are third instars just bigger versions of firsts? Bulletin of Entomological Research, v. 97, n. 1, p. 81-88, 2007.

JOHNSON, M. L.; ZALUCKI, M. P. Foraging behavior of Helicoverpa armigera first instar larvae on crop plants of different developmental stages. Journal of Applied Entomology, v. 129, n. 5, p. 239-245, 2005.

LUONG, T. T. A.; DOWNES, S. J.; CRIBB, B.; PERKINS, L. E.; ZALUCKI, M. P. Oviposition site selection and survival of susceptible and resistant larvae of Helicoverpa armigera (Lepidoptera: Noctuidae) on $\mathrm{Bt}$ and non-Bt cotton. Bulletin of Entomological Research, v. 106, n. 6, p. 710-717, 2016.

MARUR, C. J.; RUANO, O. A reference system for determination of developmental stages of upland cotton. Revista de Oleaginosas e Fibrosas, v. 5, n. 2, p. 313-317, 2001.

MOTA-SANCHES, D. M.; WISE, J. C. Arthropod pesticide resistance database Michigan State University. 2018. Available at: https://www.pesticideresistance.org/ index.php. Access on: 5 Apr. 2018.

NAVASERO, R. C.; RAMASWAMY, S. B. Morphology of leaf surface trichomes and its influence on egglaying by Heliothis virescens. Crop Science, v. 31, n. 2, p. 342353, 1991.

OLSEN, K. M.; DALY, J. C. Plant-toxin interactions in transgenic Bt cotton and their effect on mortality of Helicoverpa armigera (Lepidoptera: Noctuidae). Journal of Economic Entomology, v. 93, n. 4, p. 1293-1299, 2000.

PARRA, J. R. P. Técnicas de criação de insetos para programas de controle biológico. Piracicaba: FEALQ, 2001.

PASCUA, L. T.; PASCUA, E. M. The distribution and movement of cotton bollworm, Helicoverpa armigera Hübner (Lepidoptera: Noctuidae) larvae on cotton. Philippine Journal of Science, v. 131, n. 2, p. 91-98, 2002.

PERKINS, L. E.; CRIBB, B. W.; BREWER, P. B.; HANAN, J.; GRANT, M.; TORRES, M.; ZALUCKI, M. P. Generalist insects behave in a jasmonate-dependent manner on their host plants, leaving induced areas quickly and staying longer on distant parts. Proceedings of the Royal Society B, v. 280, n. 1756, 2013. Available at: http://rspb. royalsocietypublishing.org/content/280/1756/20122646. Access on: 21 Sep. 2018.

PERKINS, L. E.; CRIBB, B. W.; HANAN, J.; GLAZE, E.; BEVERIDGE, C.; ZALUCKI, M. P. Where to from here?: the mechanisms enabling the movement of first instar caterpillars on whole plants using Helicoverpa armigera (Hübner). Arthropod-Plant Interactions, v. 2, n. 1, p. 197-207, 2008. 
SANTOS, W. J. Manejo das pragas do algodão com destaque para o Cerrado brasileiro. In: FREIRE, E. C. (ed.). Algodão no Cerrado do Brasil. Brasília, DF: Abrapa, 2015. p. 267-347.

SILVA, I. F.; BALDIN, E. L. L.; SPECHT, A.; SOSAGÓMEZ, D. R.; ROQUE-SPECHT, V. R.; MORANDO, R.; PAULA-MORAES, S. V. Biotic potential and life table of Helicoverpa armigera (Hübner) (Lepidoptera: Noctuidae) from three Brazilian regions. Neotropical Entomology, v. 47, n. 3, p. 344-351, 2018.

TOPPER, C. P. The dynamics of the adult population of Heliothis armigera (Hübner) (Lepidoptera: Noctuidae) within the Sudan Gezira in relation to cropping pattern and pest control on cotton. Bulletin of Entomological Research, v. 77, n. 3, p. 525-539, 1987.
TORRES, J. B.; RUBERSON, J. R. Spatial and temporal dynamics of oviposition behavior of bollworm and three of its predators in Bt and non-Bt cotton fields. Entomologia Experimentalis et Applicata, v. 120, n. 1, p. 11-22, 2006.

VENDRAMIM, J. D. O controle biológico e a resistência de plantas. In: PARRA. J. R. P.; BOTELHO, P. S. M.; CORREAA-FERREIRA, B. S.; BENTO, J. M. S. (ed.). Controle biológico no Brasil: parasitoides e predadores. São Paulo: Manole, 2002. p. 511-528.

ZALUCKI, M. P.; DAGLISH, G.; FIREMPONG, S.; TWINE, P. The biology and ecology of Heliothis armigera (Hübner) and $H$. punctigera Wallengren (Lepidoptera: Noctuidae) in Australia: what do we know? Australian Journal of Zoology, v. 34, n. 6, p. 779-814, 1986. 